\title{
Indus Water Treaty: Challenges and Prospects
}

\author{
Shoket Ali \\ Ph.D Research Scholar \\ Institute of Internationnal Relatoins \\ Shah abdul Ltif University, Khairpur \\ shaukatalimalik@gmail.com \\ Amir Ahmed Khuhro \\ Director \\ Institute of Internationnal Relatoins \\ Shah abdul Ltif University, Khairpur
}

\begin{abstract}
:
The growing water scarcity in India and Pakistan and emerging climatic and environmental changes to the Indus basin rivers system are causing a great stress on smoothing working of Indus water treaty 1960. Pakistan Being a lower riparian, facing the issue as to how to reinterpret the Indus Waters Treaty without giving up its water rights. The paper discusses that following the inbuilt constraints of a lower riparian, Pakistan need to adopt a multipronged strategy following water rationale to secure its water rights within the scope of the treaty. For this; effective implementation and enhancement of Article VI, VII, constructive diplomatic and political strategy,efficient water uses and sustainable water resource management in Indus-Pakistan
\end{abstract}

Keywords: Indus Treaty, Pakistan, India, Regional Relations, Water dispute.

\section{Introduction:}

The Indus water Treaty was signed on September 19, 1960 by the President of Pakistan Ayub khan and the prime minister of India Jawaharlal Nehru.The treaty administers how the water utilized from river Indus and its tributaries that flow in both countries so according to the treaty following rivers are to be taken by the Pakistan: Indus, Chenab, Jhelum. Other three rivers which to be governed by the India are Sutlej, Beas and Ravi.

The growing water stress between the two countries caused by climatic and environmental threats to the Indus basin river system, 
Water is emerging as a critical issue in India-Pakistan relations and can cuase conflict in south asia. The changes like demographic, hydrological, political, economic, energy environment and Himalayan glaciers melt are causing drastic pressure on effective working and, normative, functional and administrative viability of the Indus water treaty 1960.

Indus water treaty between Pakistan and India is a water-distribution treaty, which first draw by the World Bank and after International Bank for Reconstruction and Development under signed by Indian Prime minister Nehru and President of Pakistan Ayub Khan in Karachi on 19 sep, 1960 to resolve the water disputes which occur place after the 1947 division. The treaty ideals with water sharing of Indus water system which comprises of six rivers. The treaty clearly defines the level and extent of water sharing along with the rights and obligations of the two countries. According to the treaty India has control over the three eastern rivers and Pakistan have controle westren rivers, it bounds india and illustrate its limite of use. The treaty provided legal procedures to resolve the disagreements and disputes through its provided arbitration mechanism. For its implementation a bilateral commission was set up named Permanent Indus Commission (PIC). Being the survival of 1965,1971 and the 1999 Kargil and insurgency on Kashmir, the treaty is considered to be the most successful water treaty in the world.

Scientists believed that climate change would worsen water stress in the Indus basin and would cause floods like faced in 2010. Pakistan being a lower riparian is supposed to be more affected by this change than India. Due to Pakistan's geological situation and resources our salvation dependent on Indus river and any sort of indiscretion would be destructive in faver of Pakistan,

Pakistan is considering as how to defend its water rights under the treaty and thwart any Indian attempt to steal Pakistan's water after the Baglihar Dam dispute. Ways to reinterpret the IWT(Indus Water Treaty) that ensures its water security without compromising on its water rights under the treaty are also being considered 
There has been an intense debate suggesting India for the renegotiation of the treaty to gain the water sharing rights on the western rivers to maximize its control over the water of Indus water system. The option lies with Pakistan in the prevailing situation is a multi-pronged strategy following the water rationale to secure its water supply within the scope of the treaty.

- Enhancing the effective utilization of article VI regarding data sharing, and empowerment of the Indus water commission to resolve the disputes inbilateral mechanism effectively.

- Better utilization of article VII dealing with future cooperationfor initiating trans boundary watershed management, sharing of Environment Impact Assessment (EIA) of hydropower projects, and commissioning of joint environmental studies.

- Effective strategy to resolve disputes, conflicts and issues on diplomatic and political level and empowerment of World bank to act effectively for the implementation of the treaty. Asking western countries to help Pakistan improving its water infrastructure.

- Pakistan needs to adopt an effective internal water resources management strategy dealing with the all potential ecological challenges and threats having indigenous physical and human resources.

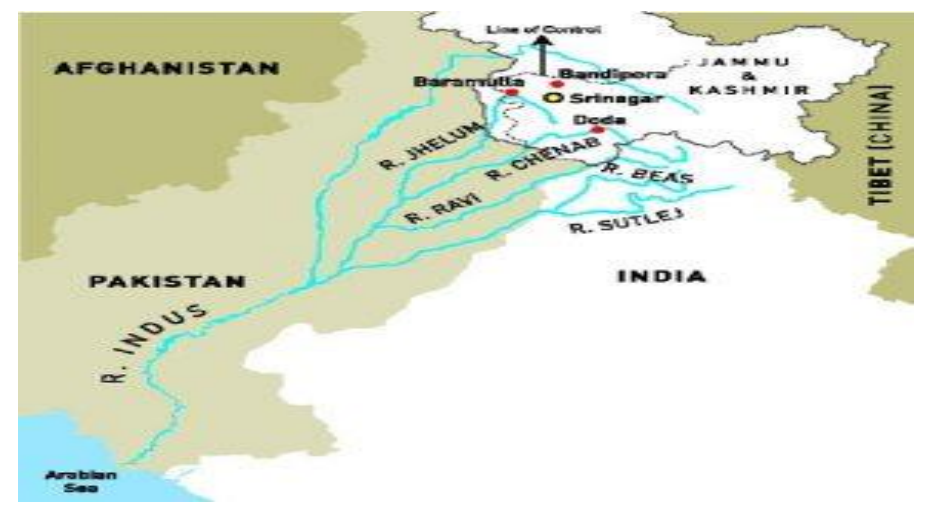

Source: https://currentaffairs.gktoday.in/tags/indus-waters treaty 
This research paper focuses on various prospects and implications of the treaty between both countries and Indian aims and objectives in the abrogation of Indus water treaty. It is a mutual accord of both countries (India-Pakistan) on six rivers signed in 1960 but now the Indian government trying to exit from this treaty. It will emphasize on the scraping of Indus water treaty and its impacts on the economy, society, politics and regional peace or security of South Asia.

\section{Significance of Treaty for Pakistan:}

This research work should mainly focus on an important and historical mutual accord on the issues of water in 1960. The accord signed between two rival countries India-Pakistan. The rivers are an important element in the life line of societies, human beings, vegetation and the civilizations. The Indus water treaty is also related to the rivers water distribution between two countries equally. Like many other international treaties, Indus Water Treaty is also has its own specification, significance and provisions to govern its operations. In other words, extensive verity and international assurance which binds india and Pakistan into a nonexit partnership with mutual interest.

The Indus water treaty has rendered a number of economic benefits to the region in terms of ensuring water supply for the irrigation needs of both India and Pakistan. A number of hydropower plants of both countries are being installed and operated under the framework of Indus Water treaty. Thus, both countries directly or indirectly bounded with the Indus water treaty for the implication of their many projects related to hydropower, irrigation and commerce as well.

The review of existing data along with its related documents and analysis of the data with reference to its research questions in order to identify the data gaps in answering those questions enhances the significance of the research work.

Indus water treaty which allocates 3 rivers each to the both countries imparting Pakistan the control of the three western rivers which are accounting for $80 \%$ of the entire basin water is really a very good 
deal for Pakistan. Because of the downstream flow of Indus basin water from India towards Pakistan, revoking the IWT would mean to give the control over this water to India and in India's ability to have enough storage capacity through the dams it means depriving Pakistan from water access of these three rivers altogether.

Pakistan highly depends on these three western rivers mainly the Indus River. For irrigation and human consumption purposes, the Indus is the sole source of water in various areas of the country especially the Sindh province. Any cut off or mere a reduction in access to these three rivers will cause catastrophic damage towards Pakistan's water security. That's why, using water as a war weapon could be more drastic for Pakistan as compare to other forms of war threats.

With annual water availability of around 35,300 cubic feet per capita, the scarcity threshold, Pakistan is ranked among the most water stressed countries around the world by the international Monetary Fund According to its recent research. The Pakistan economy is consideredto be the most water intensive in the world facing alarmingly low levels of water to work with. ${ }^{1}$

Articles VI and VII of the treaty deals with the "exchange of data" and "future cooperation" respectively. The aim of these articles is to ensure the implementation of treaty with cooperation of the parties involved along with the future collaboration for the optimum development of the Indus Rivers.

In the absence of sharing all information regarding data and the hydropower projects on the western rivers in timely manner, Article VI on exchange of data is facing great problems in implementation in Pakistan. This improper and inefficient data exchange is creating distrust causing panic reactions. Followed by the perception of stealing water by India. Pakistan is increasingly resorting to third party dispute resolution mechanism. Which is causing cost to the parties in both time and money terms and also undermining the efficacy of the institution of Indus Water Commission.

\section{Current Scenario \& IWT:}

Water sharing treaty between Pakistan and India survived through the most difficult times including the 1965 and 1971 wars and the Kargil conflict of 1999, is being threatened to be scraped by India. The reason - Modi government due to its own domestic political 
compulsions find it convenient to threaten water wars against Pakistan.

After the partition of the subcontinent there was uneven water distribution as India, being upper riparian, gained the control over the canal headwork's that supplied water to the lands which came in Pakistan share. Signed on September 9, 1960 with the cooperation of World Bank after several rounds of earlier negotiations and other interim agreements did not solve the water sharing problem between Pakistan and India, IWT got survived all ups and downs of IndiaPakistan relations unlike other agreements and CBMs that vanished into thin air once the relations soured between the two countries. The current phase of tension between the two countries started following the assassination of a young Kashmiri freedom fighter BurhanWani in recent years which led to massive protests across the Indian held Kashmir that resulted not only in deaths of innocent protesters but the use of pallet guns by Indian Security forces that also blinded hundreds of Kashmiri youths.

Days before Pakistan was about to raise the gross human rights violations of the Kashmiri people at the hands of Indian security forces in the UN General Assembly Session, an attack was launched at a military base in Uri sector. ${ }^{2}$ Since then, while blaming Pakistan, India has tried everything at its disposal to isolate Pakistan internationally. As a non-military mean to put pressure on Pakistan or to ruin Pakistan's economy, India also threatened Pakistan with dire consequences including the review of Indus Water Treaty and exploiting the Western rivers that were assigned to Pakistan under the IWT. The Modi government even went to the extent of announcing of forming an Inter-Ministerial Task Force for the review of the Treaty saying that "blood and water cannot flow together". ${ }^{3}$

Similar references were again made by Indian Prime Minister recently regarding the waters of Eastern rivers that are under Indian control. While addressing a rally in Bathinda, Punjab, Prime Minister Modi expressed his nefarious design of stopping "every drop of this water" to Pakistan. He criticized previous governments and said that because of the negligence of successive governments water kept flowing to Pakistan and our farmers remained deprived of it. As his water management strategy he constituted a task force to take aggressive control over its rivers 
For Pakistan, such statements are not only provocative, but also highly irresponsible. Mr. Sartaj Aziz being former Advisor to the Prime Minister on foreign affairs indicate india that any progress on such issue would be considered as act of war". ${ }^{4} \mathrm{He}$ also rightly pointed out that this would set a wrong example in the region, as well as around the world.

Despite such provocations, one can only hope that these statements are made more for domestic consumption. Besides his repeated promises of being tough on Pakistan if elected to power throughout his election campaign, the approaching state elections in Punjab which are due to be held between the months of February and March 2017 are also perhaps the reason for this anti-Pakistan rhetoric. In his effort to woo the farmers, as well as the general public of Punjab, Modi may have thought it to be the best tactic to play the Pakistan card.

Currently, the Indian masses are outraged and protests are being held throughout India. For Modi, making statements against Pakistan could be a desperate effort to divert the attention of people from these problems and improve his standing in the eyes of the Indian masses.

Apart from the Punjab State elections and the impacts of government's economic policies on people, the fact that the Kashmiri people are keeping their struggle alive and are rendering supreme sacrifices and which is not being missed by the international community could also be a reason for Modi to launch this onslaught against Pakistan in a bid to divert the attention of the international community from the prevailing Kashmir' situation. Since Pakistan is ranked by IMF as one of the water stressed countries and a major portion of its GDP depends on agriculture, Pakistan cannot and should not ignore these developments. Though it has already made it clear to India that any such move would certainly have severe repercussions for the region, it is also need of hour that international community is made aware of Indian intentions and its impact on Pakistan. Regional countries, especially Bangladesh and Nepal, who also have water sharing disputes with India should also be made to realise that in future they also might have to face similar situation. Furthermore, in order to meet any eventuality, Pakistan should also work to present its case from legal and technical aspect effectively in case India goes ahead with its 
stated intentions and the matter is ultimately referred to any international forum for arbitration. Pakistan also need to keep a close eye on the dams that are already being built by India or are being planned, to counter any violation of the IWT without any delays.

It is indeed extremely unfortunate that in order to get short-term political gains or to divert attention of the Indian masses and the international community from the disastrous economic policies, Prime Minister Modi is stroking hatred among the people of two countries. These feelings of hatred and revenge are being intensified when the people of Subcontinent need peace more than ever before and more cooperation to fight the common enemies like poverty, and food shortage. By stopping the waters to Pakistan, India would not only be morally wrong and violator of international law (as there is no clause in the Treaty that might give right to either India or Pakistan to renounce the Treaty unilaterally), but will also be solely responsible for the horrendous consequences it will have on humanity, be it in the form of a famine or the devastation caused by a war. Unilateral withdrawal or denying Pakistan its due share of water would not serve India's purpose. Instead, it would badly damage the image that India wishes to show to the international community. No sane mind would ever support this kind of a move that is meant to endanger lives of millions of people. It also has to be realised by India that BurhanWani was not a Pakistani nor thousands of people who came out to protest his killing were Pakistanis. Unless India understands the aspirations of the Kashmiri people with an open heart and mind, the fate of around 1.7 billion people of South Asia will remain hostage to an uncertain future and a dwindling peace in the region.

\section{Pakistan Reaction on Scraping of Treaty:}

The terrorist strike in Kashmir and the views discussed by some Indian commentators to use the treaty as a non-military war weapon against Pakistan, Tension between the two countries is again at a peak. The incident of URI attack the Indian National Union Government decided to suspend the negotiations under Indus water treaty. Decision in this regard was taken by meeting chaired by Prime Minister Narendra Modi, attended by National Security Advisor (NSA), foreign secretary, water resources secretary and 
senior PMO officials. The decision undertaken in the meeting was to the abrogation of the Indus Waters Treaty.

- It was decided to utilize water under India's share to fullest.

- Until terrorism stops, the negotiation of the issues on PIC are to be Suspended

- It was reviewed the suspension of the Tulbbul (1987) navigation project that was objected by Pakistan. Build more run-of the river hydro power projects on the rivers on which India gained the control.

- Expedite construction of Pakal Dul, Sawalkot, Bursar dams in Jammu and Kashmir. Use $20 \%$ of river water allocated under treaty for Jammu and Kashmir farmers.

Pakistan has warned India against breaching treaty $\left(21^{\text {st }}\right.$ October 2016) that all the measures will be taken to secure Pakistan's water rights if the treaty will be violated by India unilaterally and the situation will be closely monitored.

\section{India Using water as Weapon}

An Indian author Brahma Chellaney wrote that India should create a serious threat as to abrogate the treaty to make Pakistan realize not to cause harm to India to secure its water supply, other commentator as Yashwant Sinha previously holding government office as foreign minister and finance minister also suggested the same. Indian Government officially spoke out little in this regard to answer a question the spokesperson of India's Ministry for External Affairs just said that for the successful working of such treaty the mutual cooperation and trust is crucial.

- World Bank act reservedly in this entire situation merely giving the statement that its role in the treaty is limited and strictly procedural.

- The same was said by Ashok Awain that World Bank' role is related to its implementation rather than its abrogation.

- All that World Bank might do is to appoint a "neutral expert" or set up a Court of Arbitration. 


\section{India Condemned the Scraping of Treaty:}

As Indian perspectives that it is not having the enough water storage capacity to create the problem of stoppage of water. For this purpose it has to increase and enhance its dams. Temporary stoppage can be done but the diversion of the flow is not possible in Kashmir valley.

Uttam Sinha said that instead of abrogation of the treaty India can act within the treaty aggressively to use up to 3.6 Million Acre Feet (MAF), well within the norms in the treaty to give Pakistan a strong message.Violating the treaty would cause serious damage to India's international image along with causing distrust among the neighbor countries having water treaty with India. Moreover such unilateral withdrawal by India will bring World Bank into dispute.

Despite of the fiery statements from the commentators and media persons in India, the silence of the main parties involved indicates that the treaty is safe at least for the time being. Former chief minister of the Jammu \& Kashmir, Omer Abdullah said that the treaty survived four wars and will be safe in future too? Jammu \& Kashmir placed the demand to review the treaty not meeting the development needs of the state mainly hosting three rivers allocated to Pakistan.

MedhaBisht argued that out of six rivers mentioned in the treaty two are hosted by China and there India is itself middle riparian and there is no treaty between India and china in this regard. In the light of Pak-China friendly relations violation of the treaty will cause aggressive response by china. All these shows that such treaties survive not merely on the basis of trust but for the sake of interests for all the nations involved.

\section{Effects of the Dissolution of Treaty:}

It is most important to elaborate that after effects of the cancellation of Indus Waters Treaty on both countries. There is mentioning some main effects, political, economic, legal and environmental etc. 
India will likely gain a bad reputation at home and abroad because this is the only water treaty between the two arch-rival countries of South Asia that has withstood the tests of diplomatic crises and wars. Scanning through the regional and international media, the reaction of international community is already critical of Indian threats of unilateral abrogation of the treaty in the wake of the Uri incident. A number of countries, including China and the US, have asked India and Pakistan to mutually resolve the issue conveying their disapproval of termination of the treaty. After 1947, IWT is the first and only presented form of conciliation between the two countries in subcontinent. It considerd as a biggest accomplishment for a long time.

An important political implication of Indian withdrawal from the IWT an example would be setting for other countries in the region to follow suit. China shares eight per cent of the total Indus River Basin. Both Indus and Sutlej rivers have their headwaters originating from China providing a total inflow to India in the Indus Basin system at $181.62 \mathrm{~km}^{3}{ }^{5}$ The great Brahmaputra River of India, known as YarlungTsangpo in China, originates from the latter, making it an upper riparian in relation to India. Not only do China and India lack a bilateral institutional mechanism for dispute resolution over the shared waters of Brahmaputra, they are also in conflict about the ownership of South Tibet (known as Arunachal Pradesh in India). India also has concerns about Chinese diversion plans of Brahmaputra River upstream. ${ }^{6}$

Indian bullying water politics with its lower riparian in the region could become disastrous for its own future water sharing as a lower riparian vis-à-vis China and Nepal. Thus Indian government is only involved in using threats and pressures to bow down Pakistan on the issues of Kashmir and terrorism. Real abrogation is not an easy step, and India is well aware of the political implications of such a move.

\section{Legal Effects:}

According to the Vienna convention on the law of treaties (VCLT) - a customary law, there is no provision of a unilateral right to withdraw from international treaties, yet India is not a signatory to the convention. In 2011, the Supreme Court of India recognized that 
the Vienna Convention contained many principles of customary international law. ${ }^{7}$ The court specifically highlighted the provision in the VCLT (Vienna Convention on the Law of Treaties) that the treaty must be interpreted with good faith in all aspects. Considering the application of the VCLT and the past practices of the Indian government with regard to this in matters relating to international treaties, the following discussion on rules of the VCLT regarding "termination, denunciation or unilateral right of withdrawal from a treaty" is quite pertinent within the context of the IWT.

The convention only provides limited circumstances for the exercise of such a right. There are three 'grounds to invoke' as specified in Articles 42 to $62:{ }^{8}$

- Right of withdrawal provided by the treaty itself or decided by the mutual consent of all the parties involved

- The treaty is to be terminated or suspended by the contracting parties

- Termination arising as an outcome of a legal rule independent from the intentions of parties involved (for instance, inconsistency with a fundamental internal law, possibility of error in the treaty, treaty inducement, treaty conflicting with general international law, conclusion of a preceding treaty, material breach, impossibility of performance, and change of circumstances)

Rejecting unilateral right of withdrawal at will, the International Law Commission (ILC) further clarified invoking certain grounds to terminate or depart from a treaty in an official commentary:

Articles 65 to 67 of the VCLT also stipulate several provisions dealing with the matters related to the suspension, termination, or withdrawal of an international treaty.

India cannot stop water for Pakistan under customary international law even after an attempted withdrawal from the treaty because the VCLT (Article 43), being the customary international law regarding international treaties, obliges a state to "refrain from fulfilling any of her duties defined under customary international law."9 


\section{Economic Effects:}

The treaty partitioned the Indus Basin between the two parts of Punjab in India and Pakistan, and three out of the total six major rivers of the basin (Beas, Sutlej, and Ravi) were given to India for her exclusive use while binding India to let flow the water of the other three (Chenab, Indus, and Jhelum) for unrestricted use of Pakistan with minor rights for India. India constructed major canals and dams on the rivers under its control to feed Chandigarh, Haryana, Himachal Pradesh, IHK (Indian Held Kashmir), Punjab, and Rajasthan. Within Indian Punjab, multipurpose projects were undertaken to expand the irrigation and storage infrastructure in the post-independence period. After the Indus water treaty the resource planning of India including linking rivers through canals and constructing dams, is great leading the irrigated area to grow turning the country to a self-sufficient and food exporting country.

Indian hydropower projects on both eastern and western rivers are another success story of the Indus Basin system.Irrigated areas in the basin have grown as a result of huge water infrastructural investments leading the economies of the two countries towards agricultural boost along with the encouragement of development of groundwater resources.

\section{Effects on the Environment:}

Indian desire to convert Pakistan into a desert by with holding water supplies to the latter will inundate lands in IHK and Indian Punjab. The environmental fallout would hit both the countries displacing millions of people and inviting an unquestionable international reaction. ${ }^{10}$ The Indian desire to seek unilateral development of the Indus Basin by building huge dams upstream and utilizing full hydropower potential of Chenab, Indus, and Jhelum would destroy the ecology of the whole region. Massive engineering structures as planned by India across the basin to divert water from Pakistan will disturb natural hydrological cycles of rainfall and glacial melt. Furthermore, without a trans-boundary exchange of knowledge about climate change and its effects on water resources, ecology of the basin will remain threatened. Thus, a hurried Indian withdrawal from the only bilateral water treaty ever concluded between the two countries would only disrupt the management of environmental 
flows in the predictable long term. Therefore, a solution to the existing and future environmental problems in the region is not a withdrawal from a water-sharing accord, but a sustainable institutional response either by adjusting the existing framework to new needs of bilateral cooperation or through creating opportunities for other innovative institutional measures.

\section{Impact of Indus Water Treaty on South Asia:}

According to Reports from 2016 to 2050 Water deficiency leadind the world to devastating point. Asia and other rapidly populated regions open the new doors for the sudden adversity, currently center of attention is to make stronger the weak issues faced by asia in coming days. By 2050, global population of 9.7 billion demand of the water will boost and will cause uncertanity among the regions.But the challenge will arise especially for those areas who are furtile and heavily water dependent and one of the biggest consumers of water. As the India was in breach of Indus water so the use of the rivers water sets out a mechanism for collaboration between the India and Pakistan.

\section{Disagreement About IWT:}

Pakistan disagree about the construction of the dams on respectively a tributary of the Jhelum and the Chenab Rivers. Hydroelectric power plants Kishenganga and Ratle are becoming the most critical issue between both countries Pakistan and India, the technical design features contravene the Treaty.

During previous months Pakistan and the other country tried to solve their issue in different ways as Pakistan refers the issue to the Treaty Commission but India was interested to resolve it by a Neutral Expert. on Decembe 2016 these issues were converse but still unsettled. 
Accoring to it we find disputes between India and Pakistan some of are Dispute is also shown in figure below.

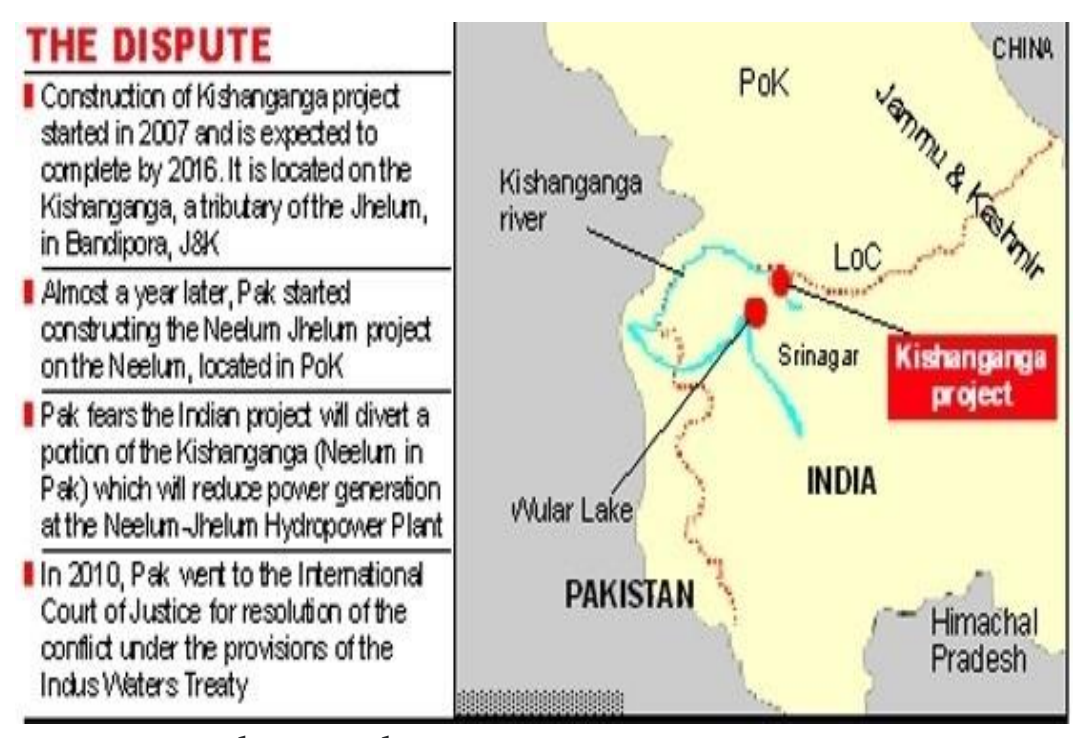

source: google.com.pk

The Pakistan fears is regarding project is as: the Indian project will divert a portion of the kishanganga wich will affect Neelum river in Pakistan as well as Jhelum Hydropower plant will distress.

By 2022 in Asia results will become worse if the development for the region will not be planned smoothly regarding the availability of the basic requirements of water, Asia will faceed lots of clashes due to unplanned, violent conflict so we must avoid them as soon aspossible.

\section{Safeguard the Treaty}

There are many reasons behind the safeguard of the treaty, as the preservation from the wars is dependent on the avoid from the disagreements. In South Asia water problem is envisage as one of the main cause of the battle. India and Pakistan have lots of conflicts since partition but after.The treaty provides negotiation mechanism to solve disputes regarding water court of arbitration is a sevenmember arbitral tribunal for the solution of disputes, The World Bank's role in this matter is restricted and dependent on the demand of the parties.To safeguard treaty many steps to be taken as different 
times for example World Bank Group President Jim Yong Kim pause taking further steps requested by the parties, at the same time the matter to the processes sought by each of the countries for friendly relationship that underpins the Treaty. World Bank Finance ministers were involed by the President of The World Bank to resolve the issue between the opponents. As well as the Vice President of The World Bank follow the pattern for the progress in status. Lots of proposals have been discussed how to resolve the disagreement in good will and friendly atmosphere.

\section{Strategy of China and its Impact on Asia}

As China observer member is showing increasingly assertive tendencies and Indus originates from Tibet it can create critical situation in south asia for peace, India and Pakistan evenly dependent on the future decision by the china for the providence of the states in term of the basic need as water. Tibet wich is consider as a sovereign Region can create hurdles for one of the main Indian river's upper course, regarding avoid the threaths and for the benefits of the country. Indian government took stand to evaluate the plan last year between the asian neighbors Thus it refers the negativity among the neighbors which led them to the war in continent asia.

Researchers assumed Brahmaputra is reflect on protective ways for China and can be used against India and have threats for forces as the water of the rivers deliberately used as a destruction during war. Same security concern raised by Pakistan, that India may adaptable the Kashmir rivers will be damed by the india exercise a strategic advantage during the war with Pakistan. Indian experts say China will use the river water of the main Indian rivers for negotiation diplomatically. Pakistan can usu $80 \%$ water from Indus bur India is restricted regarding the use of water for fullfiling its needs from Indus. Pakistan, India and Bangladesh are river-water sharing treaties, China only sharing collaboration with this treaty regarding hydrological data but its impact is very strong regaring desputes in south asia.

Indus water treaty is seen as one of the most mature international treaties and a exemple of water sharing resources but also has 
survived frequent tensions not only between the two countries but it has continued to operate despite several wars as well in south asia and the best given the ways for conflicts. Dams have enormous benefits but with the passage of time basic needs will increase mainly water so suggest that safty of the resources must be on latest bases for without comprehensive water-sharing treaties. Indus water treaty is not ideal as it is only about the division of water we did not find management of the basin, thus it has continued to operate despite several wars in asia and the best given the situation for disaster.

\section{Conclusion:}

The climatic, environmental, developmental, demographic threats to the Indus basin, the treaty is facing serious pressure and functional stress. In the prevailing situation, emerging challenge is the Indus water resource management to the two countries. The inbuilt constraints in the treaty for Pakistan causing big dilemma of reinterpreting the treaty. The fatly growing water scarcity, dams' structural issues, improper data exchange are the constraints of the efficient functioning of the treaty. Article VI and VII are crucial to resolve the conflicts by data sharing and cooperation in efficient and effective manner and the work needs to be done on these articles.

The trust issue should be resolved by proper communication and timely data sharing at political and diplomatic level. The commission constituted as Indus Water Commission needs to be strengthened in respect of its resource, scope, capacity and empowerment.The treaty has its own specific provisions to govern its operation and could only be terminated by being replaced with another treaty on a similar subject between India and Pakistan. If legally analyze then it clears that the treaty is a non-exit partnership with wide-ranging international commitments and customary bindings. Politically too, a breach of international commitments is tantamount to earning a worldwide disgrace. 


\section{References:}

1 Michael Kugelman, "Why the India-Pakistan war over water us so dangerous", in Contemporary Affairs edited by M. ImtiazShahid,(Lahore: Advance Publishers): 130-31

2 "18 Jawans Killed in Pre-dawn Strike at Uri," The Hindu, September 18, 2016

3 "PM Modi Reviews Indus Water Treaty, says 'blood and water can't flow together'," Times of India, September 26, 2016

4 "Revocation of Indus Waters Treaty can be taken as an act of war: Sartaj Aziz," Dawn, September 27, 2016

5 Food and Agricultural Organization of the United Nations, Indus Basin, Water Report 37 , http://www.fao.org/nr/water/aquastat/basins/indus/index.stm, accessed $29^{\text {th }}$ April 2017

$6 \quad$ For details, see Liu Peng, "YarlungTsangpo-Brahmaputra River in ChinaIndia Relations: A Case of Asymmetric Interdependence," in Regional Studies, Vol. XXXIII, No.4, Autumn 2015, pp.3-21.

7 Civil Original Jurisdiction Writ Petition (Civil) No. 176 of 2009, Supreme Court of India, p.5. <http://judis.nic.in/supremecourt/ imgs1.aspx?filename=38154>, accessed 29 April 2017.

8 Lea Brilmayer\&IsaiasYemaneTesfalidet, "Treaty Denunciation and 'Withdrawal' from Customary International Law: An Erroneous Analogy with Dangerous Consequences," The Yale Law Journal, Volume 120, 2010-2011. <http://www.yalelawjournal.org/forum/ treaty-denunciationand-qwithdrawalq-from-customary-international-law-an-erroneousanalogy-with-dangerous-consequences>, accessed 29 April 2017

9 Article 43 of the Vienna Convention on Law of Treaties, 1969

10 Betwa Sharma, "Why Engaging In Water Wars With Pakistan Is Not Really An Option For India," The Huffington Post, 28 September 2016. <http://www.huffingtonpost.in/2016/09/28/why-engaging-in-waterwars-with-pakistan-is-not-really-an-option/?utm_hp_ref=in-homepage > https://reliefweb.int/report/world/asia-s-water-politics-near-boiling-point 